\title{
Imaging-guided intervention of foot and ankle disorders
}

\author{
George Koulouris \\ From Australasian Podiatry Council Conference 2011 \\ Melbourne, Australia. 26-29 April 2011
}

Numerous degenerative, traumatic, overuse and inflammatory conditions occur about the foot and ankle both specific to the region and also as part of generalised systemic processes. The risks, benefits, indications and contraindications of common imaging guided procedures will be discussed, such as the use of corticosteroids, autologous blood, platelet rich plasma, autologous tenocytes, alcohol, radiofrequency ablation and polidocanol, to name a few. The role that these interventions perform in the treatment algorithm will also be reviewed.

Published: 20 May 2011

doi:10.1186/1757-1146-4-S1-14

Cite this article as: Koulouris: Imaging-guided intervention of foot and

ankle disorders. Journal of Foot and Ankle Research 2011 4(Suppl 1):14.

Submit your next manuscript to BioMed Central and take full advantage of:

- Convenient online submission

- Thorough peer review

- No space constraints or color figure charges

- Immediate publication on acceptance

- Inclusion in PubMed, CAS, Scopus and Google Scholar

- Research which is freely available for redistribution 